\title{
Determinants of Fertilizer Usage in Dry Season Amaranthus Vegetable Production in Kwara State, Nigeria
}

\author{
${ }^{1}{ }^{*}$ Adenuga, A.H., ${ }^{2}$ Omotesho, K. F., ${ }^{1}$ Olatinwo K. B., ${ }^{1}$ Muhammad-Lawal, A. and ${ }^{3}$ Fatoba, I. \\ ${ }^{1}$ Department of Agricultural Economics and Farm Management, University of Ilorin, Ilorin, \\ Nigeria. \\ ${ }^{2}$ Department of Agricultural Extension and Rural Development, University of Ilorin, Ilorin, \\ Nigeria \\ ${ }^{3}$ National Institute of Cereal Research, Badeggi, Niger State, Nigeria. \\ *Corresponding Author: adenuga4you@yahoo.com
}

\begin{abstract}
Amaranthus vegetable is often considered as one of the most important leafy vegetables in the tropics because of its high dietary value. In spite of its importance however, its production fall short of the ever increasing domestic demand for it. Soil nutrient depletion following intensification without proper soil fertility management practices hve been identified as one of the most important factor militating against its production. This study therefore carried out an assessment of the usage of recommended soil fertility management practices in dry season amaranthus vegetable production in Kwara state, Nigeria. A three-stage sampling technique was used to select a sample of 120 amaranthus vegetable farmers for the study. Major tools of analysis used for the study were descriptive statistics and the logistic regression model. The result of analysis revealed that the usage of recommended soil fertility management practices in the study area is low. Furthermore, results of the logistic regression model showed that farm size, contacts with extension agents and the educational status of the farmer had significant effects on the usage of recommended soil fertility management practices in the study area. The study therefore recommends that government should employ and train more agricultural extension agents to cater for the majority of farmers who lack access to information on the usage of recommended soil fertility management practices. Also, the farmers should be given appropriate orientation on the need to cultivate manageable farm size to ensure increased productivity and sustainability of available land put into use.
\end{abstract}

Keywords: soil fertility management, Chemical Fertilizer, Manure, Amaranthus vegetable, logistic regression model.

\section{INTRODUCTION}

The term 'vegetable' applies to those plants and plant parts that are edible, especially leafy or fleshy parts that are usually eaten with staples as main courses or supplementary foods in cooked or raw forms. It is estimated that there are at least ten thousand $(10,000)$ plant species used as vegetables worldwide although only about fifty (50) are of great commercial value (ShingJy \& Hsiao-Feng, 2003). Amanranthus vegetable is often considered as one of the most important leafy vegetables in the tropics because of its dietary value containing per 100g, 92 percent water, 
$4.0 \mathrm{~g}$ carbohydrate, $2.5 \mathrm{~g}$ protein, $0.16 \mathrm{mg}$ riboflavin, $2900 \mathrm{IU}$ vitamin $\mathrm{A}, 43 \mathrm{mg}$ vitamin C, $215 \mathrm{mg}$ Calcium. $0.7 \mathrm{mg}$ Niacin, $80 \mathrm{mg}$ ascorbic acid, $0.3 \mathrm{~g}$ fat and $0.03 \mathrm{mg}$ thiamine (United States Department of Agriculture, USDA, 1999). The importance of vegetable in the diet of most Nigerians can therefore not be overemphasized. It is recognised as one of the best resources for overcoming micro nutrients deficiencies (Shwindu, 2002). Generally, per capita consumption of vegetables is only $100 \mathrm{~g}$ in developing countries including Nigeria compared to $220 \mathrm{~g}$ in the more advanced countries (Idah, Ajisegun \& Visa, 2009). Nigeria, like most other developing countries, is currently faced with the problem of producing adequate food for her teeming population. The country has an estimated land area of about 98.3 million hectares, out of which about 75 percent are cultivable and an estimated population of over 140 million (National Planning Commission, NPC , 2006). A sustainable production of vegetables to meet the demand of the nation's enormous population is of great concern (Oladoja et al, 2006). This is because the domestic demand for them is met essentially from local production and importation of fresh vegetables into the country is uncommon (Ibrahim, \& Omotesho, 2009).

The failure to match supply of vegetables and other food to demand is mainly attributed to soil nutrient depletion following intensification without proper land management practices (Adesanwo, Adetunji, Adesanwo, Osiname,Torimiro and Dialta 2009; Jayne, Daniel, MuchoruMuna, Jona, Roel, and Bernard, 2008; Sanchez \& Jama, 2002). Yields are decreasing on continuously cropped land without nutrient inputs, and fallowing is no longer practicable due to the high population pressure (Cleaver \& Schreiber, 2007). Tremendous socio-economic transformations and geophysical changes are observed to render the traditional farming systems unsustainable. Given the increasing fragmentation of land and the reduced ability to use traditional soil fertility management practices, the vegetable farmer is left with no other option than to increase the use of soil amendments mainly organic and inorganic fertilizers. However, the wrong use of these inputs results in adverse environmental consequences contributing to the already worrying climate change and possible negative net returns result from low crop yields.

To increase the availability of vegetables especially during the dry season when prices are usually very high due to low yield emanating from unavailability of suitable land for the numerous producers, an assessment of the soil fertility management practices used in dry season vegetable production becomes very imperative. Sustainable soil fertility management is crucial to minimising land degradation, rehabilitating degraded ones and ensuring optimal use of land resources for the benefit of the present and the future generations. Efficient and correct use of soil fertility management practices in dry season vegetable production would increase output, thereby increasing income and consequently solves the serious problem of food imbalance and malnutrition in the country. While a number of alternative soil fertility management options have been developed, very few studies have been carried out to assess the level of their usage and the factors influencing their usage, particularly in dry season vegetable production. Adunni and Werner (2007) studied the socioeconomic determinants of household fertilizer use intensity for maize-based production systems in Northern Guinea savanna of Nigeria using data collected from 160 households. The result of the binary logit model revealed that previous year's income 
land ownership, engagement in off-farm activities and years of experience in maize farming were the significant factors that influenced fertilizer use intensity. Also using the binary logit model, Kaburu (2002) found out that education level of the farmer and access to credit were the significant factors determining fertilizer usage by small scale farmers in Kenya. This study would therefore add to the existing literature on the determinants of usage of recommended soil fertility management practices. The objectives of this study therefore were to:

(i) determine the level of usage of recommended soil fertility management practices in dry season amaranthus vegetable production;

(ii) ascertain the determinants of usage of recommended soil fertility management practices and

(iii) identify the constraints against usage of recommended soil fertility management practices in dry season amaranthus vegetable production

\section{Area of Study}

\section{METHODOLOGY}

The study was conducted in Kwara State, Nigeria. The State consists of sixteen (16) Local Government Areas. The State is located in the central part of Nigeria within latitude $7^{\circ} 45^{\prime}-9^{\circ} 30^{\prime} \mathrm{N}$ and longitude $2^{0} 30^{\prime}-6^{\circ} 25^{\prime}$. The population of the state is put at 2,371,089 and covers an estimated land area of $32,500 \mathrm{~km}^{2}$ out of which $75.3 \%$ is cultivable. The topography is mainly plain to slightly gentle. The State has two main climatic seasons, the dry and wet season. Annual rainfall ranges between 1000 to $1500 \mathrm{~mm}$ while the average temperature lies between $30^{\circ} \mathrm{C}$ and $35^{\circ} \mathrm{C}$. Agriculture is the mainstay of the economy in Kwara State as it accounts for about 70 per cent of the labour force. The climate is conducive for growing fruits and vegetables, such as mangoes, pineapples, bananas tomatoes and leafy vegetables (Kwara State Agricultural Development Project, KWADP, 2006). The State is divided into four main agro-ecological zones in consonance with the ecological characteristics, cultural practices and administrative convenience by the Kwara state Agricultural Development project as given below:Zone A: Baruteen \& Kaima; Zone B: Edu and Patigi; Zone C: Asa, Ilorin East, Ilorin South, Ilorin West \& Moro; Zone D: Ekiti, Ifelodun, Irepodun, Isin, Offa, OkeEro \& Oyun (KWADP, 2006).

\section{Sampling Technique}

The target population for this study is dry season amaranthus vegetable farmers in Zone C, Kwara State. Making use of a list of dry season amaranthus vegetable farmers in the zone, Athree stage sampling technique was used to select the sample for the study. The first stage was the purposive selection of zone $C$ due to the presence of large population of dry season amaranthus vegetable farmers in the zone (Ministry of Agriculture and Natural Resources, 2010). The second stage was the random selection of two villages from each of the five local government areas that make up the zone. The third stage comprised a random selection of 120 leafy vegetable farmers distributed across the ten selected villages. 


\section{Data Analysis Procedure}

To achieve the study objectives, descriptive statistics comprising the use of percentages, frequency and tabulation was used to describe the socio-economic and demographic characteristics of the respondents. To determine the factors influencing farmers' decision to use recommended soil fertility management practices, the binary logistic regression model was employed. We first computed a dichotomous variable indicating whether a farmer uses recommended soil fertility management or not, so as to fit-in the binary logistic regression model. The model is such that the dependent variable is converted into a dichotomous binary variable coded 0 and 1 . For this study, farmers with application rate of less than 25 percent of the recommended rate were regarded as non-users and assigned the value of 0 while those who applied 25 percent and above the recommended rate were regarded as users and assigned the value of 1. Earlier study by (Manyong et al, 2001), has shown that application of at least 25 percent of the recommended rate of fertilizer is required to expect appreciable gain on yield. The recommended rate of fertilizer application for amaranthus vegetable production is $94 \mathrm{~kg} \mathrm{~N} / \mathrm{ha}$, $80 \mathrm{~kg} \mathrm{P}_{2} \mathrm{O}_{5} / \mathrm{ha}$ and $71 \mathrm{~kg} \mathrm{~K} \mathrm{~K}_{2} \mathrm{O} / \mathrm{ha}$ (Palanda and Chang, 2003, KWADP, 2009). This is in line with earlier studies by Adunni and Werner (2007); Kaburu (2002) which adopted the binary logistic regression model to determine the factors influencing household fertilizer use intensity. Also, Kavia, Mushangi and Sonda (2007) in their study of factors affecting the adoption of fertilizer technology in cassava mosaic disease tolerant cassava varieties in Tanzania adopted the binary logistic regression and the Tobit model but came up with similar results. The logistic regression model is given as:

$\operatorname{Logit}(p)=\ln [p /(1-p)]=\beta_{0}+\beta_{1} X_{1}+\beta_{2} X_{2}+\ldots \ldots+\beta_{8} X_{8}+e$

Where:

$\mathrm{P} \quad=$ probability that a farmer uses the recommended rate $\mathrm{p}(\mathrm{Y}=1)$

$(1-p) \quad=$ probability that a farmer does not use the recommended rate $p(Y=0)$

$\mathrm{P} /(1-\mathrm{p}) \quad=$ the "odds ratio"

$\ln [\mathrm{p} /(1-p)] \quad=$ the log odds ratio, or "logit"

$X_{1} \quad=$ Education of the farmer (years)

$\mathrm{X}_{2} \quad=$ Farm size (hectares)

$X_{3} \quad=$ Household size (number)

$\mathrm{X}_{4} \quad=$ Experience of the farmer (years)

$X_{5} \quad=$ Extension contact (dummy, $1=$ yes; $0=$ no)

$\mathrm{X}_{6} \quad=$ Access to $\mathrm{credit}$ (dummy, $1=$ yes; $0=$ no)

$\mathrm{X}_{7} \quad=$ Membership of association (dummy, $1=$ yes; $0=$ no)

$\mathrm{X}_{8} \quad$ = Off-farm income (dummy, $1=$ yes; $0=$ no)

$\beta_{0} \quad=$ constant

$\beta_{1} \ldots . . . \beta_{8}$ are vectors of the respective parameters which are estimated using maximum likelihood method

$\mathrm{E} \quad=$ error term 


\section{RESULTS AND DISCUSSION}

\section{Usage of Recommended Soil Fertility Management Practices}

The proportion of the farmers who practice recommended soil fertility management as well as the type and source of information on recommended soil fertility management are as presented in Table 1.

Table 1: usage of Recommended Soil Fertility Management Practices

\begin{tabular}{|lll|}
\hline Characteristics & Frequency & Percentage \\
Usage & & \\
Users & 52 & 43.33 \\
Non users & 68 & 56.67 \\
& 120 & 100.00 \\
Types of fertilizer used & & \\
Inorganic fertilizer & 64 & 53.33 \\
Organic fertilizer & 19 & 15.83 \\
Organic and inorganic & 20 & 16.67 \\
Nil & 17 & 14.17 \\
Total & 120 & 100.00 \\
Sources of information & & \\
Extension agents & 65 & 54.17 \\
Friends and relatives & 40 & 33.33 \\
Farmers association & 15 & 12.50 \\
Total & 120 & 100.00 \\
\hline
\end{tabular}

Source: Field Survey, 2010.

As shown in Table 1, 43.33\% of amaranthus vegetable farmers used the recommended soil fertility management practices while $56.67 \%$ were non-users. Only $54.17 \%$ of the respondents indicated that they got information from extension agents, others rely on information from friends and relatives and the farmers' association. 53.33\% of the respondents used chemical fertilizers while $15.83 \%$ used organic fertilizer. $16.67 \%$ used a combination of chemical and organic fertilizer while $14.7 \%$ did not apply fertilizer at all. 
Adenuga, Omotesho, Olatinwo, Muhammad-Lawal \& Fatoba

\section{Rate of Fertilizer Application}

The farmers' rate of fertilizer application compared to the recommended rate is given in table 2

Table 2: Rate of Fertilizer Application

\begin{tabular}{|lll|}
\hline Fertilizer & Average Rate used (kg/ha) & Recommended rate (kg/ha) \\
Nitrogen & 38.38 & 94 \\
Phosphorus & 25.60 & 80 \\
potassium & 24.85 & 71 \\
\hline
\end{tabular}

Source: computed from field Survey data, 2010.

As shown in Table 2, the average rate of fertilizer application in the study area is $38.38 \mathrm{kgN} / \mathrm{ha}$, $25.6 \mathrm{kgP}_{2} \mathrm{O}_{5} / \mathrm{ha}$ and $24.85 \mathrm{~K}_{2} \mathrm{O} / \mathrm{ha}$ which is low compared to the recommended rate. The most commonly used chemical fertilizers were NPK 15:15:15 and Urea while poultry manure was the major type of organic fertilizer used by the farmers.

Factors Influencing the Usage of Recommended Soil Fertility Management Practices

As shown in Table 3, the logistic regression model explains $84.5 \%$ of the total variation in the usage of recommended soil fertility management practices. The chi square statistics showed that the parameters included in the model were significantly different from Zero at $1 \%$ level

Table 3: Parameter Estimates for the Logistic Regression Model

\begin{tabular}{|llllll|}
\hline Variable & B & SE & Wald & Sig & Exp $\boldsymbol{\beta}$ \\
Constant & $-4.114^{\star \star}$ & 1.795 & 5.255 & 0.022 & 0.016 \\
Extension contact & $3.423^{\star \star \star}$ & 1.000 & 11.710 & 0.001 & 30.662 \\
Education & $0.284^{\star}$ & 0.155 & 3.363 & 0.067 & 1.329 \\
Farm size & $-12.353^{\star \star}$ & 6.182 & 3.993 & 0.046 & 0.000 \\
Household size & 0.126 & 0.137 & 0.835 & 0.361 & 1.134 \\
Access to credit & 3.307 & 1.114 & 1.219 & 0.270 & 4.837 \\
Membership of association & 1.576 & 1.428 & 1.219 & 0.270 & 4.837 \\
Experience & -0.71 & 0.082 & 0.746 & 0.388 & 0.932 \\
Off-farm income & 1.505 & 1.161 & 1.678 & 0.195 & 4.502 \\
\hline
\end{tabular}

Model Chi-square $93.7^{\star \star \star}$

Overall case correctly predicted $=84.3 \%$

*** Significant at 1\%, ** significant at $5 \%,{ }^{*}$ significant at 10\% 
The model estimates revealed that factors that significantly influenced the usage of recommended soil fertility management practices in the study area are contact with extension agents, years of education of the farmer and farm size.

The significance (at 1\%) of extension contact variable implies that extension visit is an important factor that would promote the usage of recommended soil fertility management practices. As shown in $\operatorname{Exp}(\boldsymbol{\beta})$ statistics, the odds in favour of using recommended soil fertility management practices increased by a factor of 30.662 .

Education of the farmers was significant at $10 \%$ and positively related to usage. The implication of this finding is that, farmers with better education has the likelihood to use recommended soil fertility management practices compared to farmers with lower level of education. This is consistent with the a priori expectation. The fact that educated farmers have better access to information could contribute to this positive relationship.

The negative coefficient of farm size which was significant at $5 \%$ implies that farmers with smaller farm size would likely use the recommended technology compared to farmers with larger farm size who probably do not have enough capital to purchase sufficient fertilizer for use in their farms.

\section{Constraints to Usage of Recommended Soil Fertility Management Practices}

The 4- point Likert scale was used to identify the constraints to the usage of recommended soil fertility management practices in the study area. No doubt, these constraints if adequately addressed would result in increased productivity and consequently raise the standard of living of the farmers. The constraints confronting the usage of recommended soil fertility management practices as perceived by the farmers are presented in Table 4

Table 4: Constraints to Usage of Recommended Soil Fertility Management Practices

\begin{tabular}{|llll|}
\hline S/N & Identified constraints & Degree of Importance & Rank \\
1 & High cost of fertilizer & 4 & $1 \mathrm{st}$ \\
2 & Lack of extension advice & 4 & $1 \mathrm{st}$ \\
3 & Transportation & 3 & $3 \mathrm{rd}$ \\
4 & Non-availability of credit & 3 & $3 \mathrm{rd}$ \\
5 & Low produce price & 3 & $3 \mathrm{rd}$ \\
6 & Weed infestation & 2 & $6 \mathrm{th}$ \\
7 & Non-availability of labour & 2 & 6 th \\
\hline
\end{tabular}

Key: $1=$ not important $2=$ Less important, and $3=$ important $4=$ Very important

The most important constraints against the usage of recommended soil fertility management practices in dry season amaranthus vegetable production in the study area were high cost of fertilizer and Lack of extension advice. Other constraints identified are transportation, nonavailability of credit, low produce price and weed infestation. 


\section{CONCLUSION}

The study reveals that there is low level of fertilizer usage among the farmers. This might not be unconnected with the problem of high cost of fertilizer which makes it unaffordable for the peasant farmers. Thus, extension services to the farmers need to be improved so that farmers can access relevant information on improved technologies. In line with the findings of the study, it is recommended that the Government should employ and train more agricultural extension agents to cater for the majority of the farmers who lack access to information on the usage of recommended soil fertility management practices. The extension agents in carrying out their duties should emphasize the important of sustainable intensification of farm land to prevent wastage of resources. Education of the farmer could greatly increase the usage of recommended soil fertility management practices. The government should therefore invest more in village schools and adult education. Efforts should be made to correct fertilizer market inadequacies particularly to monitor the quality, standard and guarantee farmers' access. Being a cheaper alternative to chemical fertilizer, ways should be devised to reduce the bulkiness of organic manure through proper packaging for easy transportation and improved quality. Also, the farmers should be given appropriate orientation on the need to cultivate manageable farm size to ensure increased productivity and sustainability of available land put into use.

\section{REFERENCES}

Adesanwo O. O., Adetunji M. T., Adesanwo J. K., Osiname O. A., Torimiro D. O. and Dialta S. (2009). "Evaluation of Traditional Soil Fertility Management Practices for Rice Cultivation in South-Western Nigeria". American-Eurasian Journal of Agronomy2(2), 45-49

Adunni S. \& Wener D. (2007): "Socioeconomic Determinant of Household Fertilizer Use Intensity for Maize-Based Production Systems in Northern Guinea Savannah of Nigeria", Journal of Applied Sciences 7(13): 1774-1779

Cleaver KM, \& Schreiber G. A. (2007). Reversing the spiral, the population, agriculture and environment nexus in sub-Sahara Africa. World Bank Wahington D.C.

Ibrahim, H., \& Omotesho O.A. (2009). "An Assessment of the Sustainability of Vegetable Production under Fadama in the Northern Guinea Savannah Zone of Nigeria". Electronic Journal of Environmental Agricultural and Food Chemistry 8(11), 11561163

Idah, P. A., Ajisegun E. S. A. \& Visa, M. G. (2007). "Fruits and Vegetables Handling and Transportation in Nigeria" AU J. T. 10 (3) 175-183

Jayne, M., Daniel, M., Muchoru-Muna, M., Jona, C. B., Roel, M. \& Bernard V. (2008) "Determinant of Decision to Adopt Integrated Soil Fertility" Expl agric, 45, 61-75

Kaburu P. K. (2002): "Determinants of fertilizer use at farm level: A case study of small scale farmers in Nakuru District, Kenya". African Journal of Agricultural Research 4(4) 223235 
Kavia, F. Y., Mushangi, C. C. and Sonda, G. B. (2007): "Factors Affecting the Adoption of Fertilizer Technology: A Case of Cassava Mosaic Disease Tolerant Varieties in Lake Zone regionTanzania" African crop science proceedings 8: 1875-1878

Kwara StateAgricultural Development Project, KWADP, (2006), Agronomic Survey Report

Manyong, V. M., Makinde, K. O., Saginga, N. Vanlauwe, B. \& Diels J. (2001). Fertilizer use and Definition of farmer Domain for Impact Oriented Research in the Northern Guinea Savanna of Nigeria. Journal of Agro Ecosystems 59, 129-141

Ministry of Agriculture and Natural Resources (2010): Report of Kwara State Farmers' Census

Oladoja W. A., Akinbule L. A., \& Adisa B. O. (2006). "Assessment of Environment Related Problems and Prospects of Vegetable Production in the Peri-Urban Area of Lagos State, Nigeria". Journal of Food Agriculture and Environment. 4 (3\&4) : 271-298

Palada, M.C., \& Chang, L.C. (2003). "Suggested Cultural Practices for Vegetable Amaranth Asian Vegetable Research and Development Centre (AVRDC)". http://www.avrdc.org/LC/indigenous/amaranth

Sanchez, P. A., \& Jama, B. A. (2002). "Soil fertility replenishment takes off in East and Southern Africa". In: Vanlauwe, B., Diels, J., Sanginga, N., \& Merckx, R. (Eds). Intergrated Plant Nutrient Management in sub-Sahara Africa. CABI International, 23-46

Shing-Jy, J. T., \& Hsiao-Feng, L. (2003). "Handbook of Vegetable Preservation and Processing" Edited by Y. H. Hui , Sue Ghazala, Dee M. Graham , K. D. Murrell, and Wai-Kit Nip CRC Press

Shwindu, K. M. (2002). "Role of Africa Leafy Vegetables in Alleviating Food and Nutrition Insecurity in Africa". AJFNS 2(2): 96-97

U.S. Department of Agriculture USDA, Agricultural Research Service,( 1999). USDA Nutrient Database for Standard Reference, Release 13. Nutrient Data Laboratory. Available at, http://www.nal.usda.gov/fnic/foodcomp 